\title{
Seasonal changes in the somatic indices of the freshwater silverside, Odontesthes bonariensis (Teleostei, Atheriniformes) from a Neotropical shallow lake (Argentina)
}

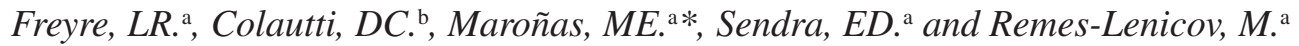 \\ aEcología de Poblaciones, Instituto de Limnología "Dr. Raúl A. Ringuelet", \\ Consejo Nacional de Investigaciones Científicas y Técnicas - CONICET, Universidad Nacional de La Plata - UNLP, \\ Av. Calchaquí Km 23.5, CP 1888, Florencio Varela, Buenos Aires, Argentina

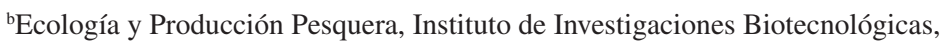 \\ Instituto Tecnológico de Chascomús, Consejo Nacional de Investigaciones Científicas y Técnicas - CONICET, \\ Universidad Nacional de San Martín - UNSAM, \\ Camino Circunvalación Laguna, Km 6, CP 7130, Chascomús, Buenos Aires, Argentina \\ * e-mail: miriam@ilpla.edu.ar \\ Received July 30, 2007 - Accepted March 27, 2008 - Distributed May 31, 2009
}

(With 3 figures)

\begin{abstract}
The study object was an Odontesthes bonariensis (Valenciennes, 1835) population of a characteristically shallow lake from the pampasic region. Over one year, zooplankton and fish samples were collected monthly. As a function of time and gender, several indices were investigated (relative weight, mesentery fat index, gonadosomatic index, hepatosomatic index and somatic index) and were related to zooplanktonic community dynamics, the main energy food source for this species. The results indicate that the seasonal information contained in the weight compartments is most important in mesentery fat, gonads and liver. The zooplankton availability modulates reserves (fat) behaviour and physiologic activity (liver), determining spawn intensity. Thus, in spring spawns, with higher zooplankton availability, mature individuals of the population, males and females, transfer energy from the food to the gonads. In autumn spawns, they use the fat reserves for gonad ripening.
\end{abstract}

Keywords: Odontesthes bonariensis, condition, zooplanktonic community, energy allocation.

\section{Mudanças sazonais nos índices somáticos do Odontesthes bonariensis (Teleostei, Atheriniformes) em uma lagoa da região Neotropical (Argentina)}

\begin{abstract}
Resumo
O objeto do estudo foi a população Odontesthes bonariensis (Valenciennes, 1835) de uma lagoa característica da região dos pampas argentinos. Durante um ano, recolheram-se mostras mensais da comunidade zooplanctônica e da população de peixe-rei. Pesquisaram-se vários índices (peso relativo e os índices de gordura mesentérica, gônadosomático, hepato-somático e somático) em função do tempo e do sexo, relacionando-os com a dinâmica de comunidade de zooplâncton, a principal fonte de energia para esta espécie. Os resultados indicam que a informação sazonal contida nos compartimentos de peso é muito importante na gordura mesentérica, nas gônadas e no fígado. A disponibilidade do zooplâncton modula as reservas (gordura), o comportamento e a atividade fisiológica (fígado), determinando a intensidade da desova. Assim, na desova de primavera, com disponibilidade mais elevada do zooplâncton, a maioria dos indivíduos maduros da população, machos e fêmeas, transferem energia do alimento às gônadas. No outono os peixes usariam principalmente as reservas de gordura para a maduração gonadal.
\end{abstract}

Palavras-chave: Odontesthes bonariensis, condição, comunidade zooplanctônica, alocação de energia.

\section{Introduction}

The silverside, Odontesthes bonariensis (Valenciennes, 1835), is the most important game and commercial freshwater fish in the Argentinean pampasic region (Gómez, 1998). Since the end of the XIX century, commercial fishing of this species has represented one of the main economic resources for several cities of this region, contributing in some cases to $45 \%$ of its total revenue (Berasain et al., 1999). Over the last decades, silverside sport fishing generated annual revenue of $\$ 700,000$ (US) for a typical city of the Buenos Aires Province (50,000 inhabitants) (Grosman, 1995). Due to the quality of its flesh, this species has been introduced into several countries of South America, Europe and Asia (Menni, 2004). Nevertheless, its exploitation has generally been developed based on the natural production of the environment, and management strategies focused on fishery sustainability have seldom been used.

In the Province of Buenos Aires, with more than 1,000 shallow lakes and scarce economic and human re- 
sources dedicated to fishery biology, studies are limited. The diagnosis on the state of the fish population and its exploitation potential has usually been based on only a few or even single samples. In these situations, standardized methods and indices for the species such as those proposed by Freyre (1976), Baigún and Anderson (1993) or Colautti et al. (2003; 2006), are important for information analysis.

Condition indices most widely used in silversides have been those of the indirect type such as the condition factor K (Freyre et al., 1983; Grosman et al., 2000, among other), relative condition factor Kn (Freyre et at., 2005) and relative weight $\mathrm{Wr}$ (Colautti et al., 2003; 2006). These three indices provide the general information of overall health and, in other species, their variations have shown relationships with food availability, seasonal fluctuation in water level, temperature, gender, reproductive cycle, age and length (e.g. Liao et al., 1995; Encina and Lorencio,1997; Blackwell et al., 2000).

The invasive or direct indices, such as gonadosomatic index, hepatosomatic or liversomatic index and mesenteric fat index, have scarcely been used in $O$. bonariensis. Strussmann (1989) estimated the time variations of these indices for silverside bred in confinement. In wild populations, only gonadosomatic index time series are registered (Boschi and Fuster de Plaza,1959; Calvo and Morriconi, 1972; Cornejo, 2003).

The use of direct indices in relation to changes of the different body compartments allows us to obtain information on the metabolic activity and to reveal the origin of the changes registered in the indirect indices. Consequently, the combined interpretation of the indices permits the assessment of physiologic responses from the individuals to internal and external factors (Liao et al., 1995; Blackwell et al., 2000; Brown and Murphy, 2004).

In this contribution, annual variation of direct and indirect condition indices (somatic, gonadosomatic, liversomatic, mesenteric fat and relative weight index) by gender for silversides from a characteristic shallow lake of the pampasic region was analysed. These variations were related to the reproductive cycle and to zooplankton community dynamics, its main source of food energy, in order to interpret the acquisition dynamics and circanual energy transfer.

\section{Material and Methods}

Sampling was carried out in the shallow lake

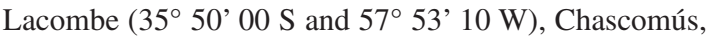
Buenos Aires Province, Argentina; a eutrophic water body with an approximate surface of $19.5 \mathrm{hm}^{2}$ and a maximum depth of $2.00 \mathrm{~m}$.

Between October, 1997 and October, 1998, monthly fish samplings were conducted in which 1,850 silversides with standard lengths between 21 and $368 \mathrm{~mm}$ were captured. Fishing gear used included a beach seine (bag: $6 \mathrm{~mm}$ mesh bar and $12 \mathrm{~m}$ floatline; wings: $10 \mathrm{~mm}$ mesh bar and $4 \mathrm{~m}$ floatline) and several gillnets of different mesh sizes $(14,19,21,25,29,34$ and $37 \mathrm{~mm}$ mesh bar). On each sampling date the catch was classified by $10 \mathrm{~mm}$ size classes. In each size class, a randomly selected subsample of 10 individuals maximum was retained. For subsample collection gender (male, female or indefinite) was assigned based on direct gonad examination. Individual standard lengths were measured with an accuracy of $1 \mathrm{~mm}$. Each fish was weighed (wet weight, Wto) and dissected to obtain somatic wet weight (Wso) after the gonad, mesentery fat and gut were removed. Also, gonad wet weight (Wgo), liver wet weight (Whe) and mesentery fat wet weight (Wmf) were obtained. The recorded precision was $5 \mathrm{~g}$ for weights up to $200 \mathrm{~g}, 0.1 \mathrm{~g}$ for those between $20 \mathrm{~g}$ and $200 \mathrm{~g}$ and $10 \mathrm{mg}$ for those under $20 \mathrm{~g}$.

For all the individuals, classified as males or females, indices $(\mathrm{Ij})$ for the weight compartments $(\mathrm{Wj})$ were calculated according to the general expression:

$\mathrm{I}_{\mathrm{j}}=\mathrm{W}_{\mathrm{j}} / \mathrm{W}_{\mathrm{to}} \times 100$

The relative weight by gender was also calculated by the allometric expression:

$\mathrm{Wr}=\frac{\mathrm{Wto}}{\mathrm{Ws}}$

using the standard weight (Ws) for this species (Colautti et al., 2006).

The Ij and $\mathrm{Wr}$ were ordered by sampling date $(t)$ and gender, and a Fourier trigonometric polynomial (Rey Pastor et al., 1987) using the least - squares technique was fitted:

$\hat{\mathrm{I}}_{\mathrm{j}}$ or $\hat{\mathrm{Wr}}=\mathrm{e}^{\sum_{\mathrm{k}=0}^{3} \mathrm{~A}_{\mathrm{k}} \cos \left(\mathrm{k} 2 \pi\left(\mathrm{t}+\mathrm{G}_{\mathrm{k}}\right)\right)}$

where $\mathrm{k}$ is the integer polynomial term order and $\mathrm{A}_{\mathrm{k}}$ and $\mathrm{G}_{\mathrm{k}}$ are constants. The polynomial fit was assessed by the coefficient of determination $\left(\mathrm{R}^{2}\right)$ between indices observed means for each date versus estimated value.

To measure the seasonal information importance in the different weight compartments, the coefficients of variation of the means index were calculated for the total samplings (Sokal and Rohlf, 1979).

Between May 1997 and October 1998 zooplankton community samples were monthly obtained by filtration of $20 \mathrm{~L}$ of surface water through $0.03 \mathrm{~mm}$ mesh plankton net. A qualitative and quantitative analysis were carried out in order to identify the zooplankton organisms and to make a recount of them. Different recognized taxa were grouped in superior taxonomic levels: Rotifera, Cladocera, copepods Cyclopoidea, Calanoidea, and Harparticoidea, their larval stadia (nauplius) and juveniles (Copepodite). The fraction corresponding to Cladocera, Cyclopoidea and Calanoidea, the main items in the silverside's diet, were transformed into calories each of $100 \mathrm{~L}$ of water and weighed by the silverside retention coefficient (Ringuelet et al., 1980). The smaller sized organisms, (Rotiphera, nauplii and copepodites) 
with a scarce importance in the silverside adult diet (Zagarese, 1991; Colautti and Remes Lenicov, 2000), were not considered. Data were arranged according to time of the year and using the same technique applied to the indices, the exponential of a Fourier polynomial was fitted.

\section{Results}

The variations throughout the year in $\mathrm{Ij}$ and $\mathrm{Wr}$ and the fitted Fourier polynomials are shown in dispersion diagrams (Figure 1), along with their coefficients of determination. The parameters of these functions by gender are presented in Table 1 . The value of $\mathrm{k}$ resulted in 3 because successive increment in the polynomial order did not increase the explained variation. The coefficients of variation of the means index are presented in Table 2.

The relative indices corresponding to the liver, mesentery fat and gonads attained maximum values and larger averages in females than in males. The widest variations were given in the Igo of females whose oscillations occurred on a scale of approximately 17 units. The variation coefficients registered the highest values in the males' mesentery fat and in the females' gonads. It is worth pointing out that male mesentery fat has a more seasonal behaviour than the gonad, while in females, both compartments present an equivalent seasonal oscillation. The variation coefficients had the lowest values for Iso and $W r$. In the case of the liver, results were similar for the two groups.

The Fourier polynomial fit for effective zooplankton was:

$$
\begin{aligned}
& \mathrm{P}(\mathrm{cal} / 100 \mathrm{~L})= \\
& \mathrm{e}^{0.75332-0.8799(\cos (2 \pi(\mathrm{t}+0.06954))+0.2218(\cos (4 \pi(\mathrm{t}-0.2527)))-0.4601(\cos (6 \pi(\mathrm{t}-1.9375)))}
\end{aligned}
$$

Cyclical superimposed functions of zooplankton, mesentery fat, liver and gonad fit are presented by gender in Figure 2. Zooplankton is scarce from January to June with a maximum value in September decaying rapidly until February.

In females, Îhe has September-October highest values and its lowest corresponding to April-May. The Îgo presents a maximum between January and February, declining rapidly with a minimum observed in May, growing from June to August to reach its upper limit in September. It diminishes quickly during October and November deriving slowly until January. The Imf presents its maximum in February; it falls abruptly until reaching its April-July minimum and then rises slowly during the rest of the year.

In males, the Îhe declines from December presenting a minimum in March, growing until July, decreasing until September-October and then presents a December secondary peak. The Igo grows from December to February; falling to the lowest during April-May, increasing again until September, to decrease to a second mini-

Table 1. Fourth order Fourier trigonometrical polynomials coefficients (A; G) by gender of fitted weight indexes.

\begin{tabular}{lccccc}
\hline & & \multicolumn{2}{c}{ Females } & \multicolumn{2}{c}{ Males } \\
\cline { 2 - 5 } Somatic & $\mathbf{k}$ & $\mathbf{A}$ & $\mathbf{G}$ & $\mathbf{A}$ & $\mathbf{G}$ \\
& 0 & 4.472339 & - & 4.519029 & - \\
& 1 & -0.04330 & 0.211168 & 0.008200 & -0.197872 \\
& 2 & 0.000929 & -0.290449 & -0.005528 & 0.042251 \\
Gonad & 3 & 0.004545 & 0.78956 & 0.001959 & -0.040537 \\
& 0 & 1.15238 & - & 0.076352 & - \\
Fat & 1 & 0.885485 & 0.17991 & 0.429711 & 0.242714 \\
& 2 & 0.432566 & -0.127872 & -0.359548 & 0.112374 \\
& 3 & 0.116968 & 0.147855 & -0.203255 & 0.384032 \\
& 0 & -1.85216 & - & -0.4722 & - \\
Liver & 1 & 3.92520 & 0.113527 & 0.631388 & -0.069970 \\
& 2 & -2.420518 & -0.373571 & 0.186482 & 0.128154 \\
& 3 & -0.958277 & -0.038477 & -0.195468 & 0.074823 \\
& 0 & 0.427985 & - & 0.063826 & - \\
& 1 & 0.296302 & -0.75993 & -0.126472 & -0.068669 \\
& 2 & 0.085118 & 0.453122 & 0.180680 & 0.015141 \\
& 3 & 0.040168 & -0.055074 & -0.065494 & -0.056729 \\
& & -0.026495 & - & -0.044728 & - \\
& 0 & 0.07986 & 0.169864 & 0.069412 & 0.15329 \\
& 1 & 0.024852 & -0.106773 & -0.034674 & 4.258852 \\
& & 0.010033 & -0.101805 & -0.008747 & 1.288362 \\
\hline
\end{tabular}


Females
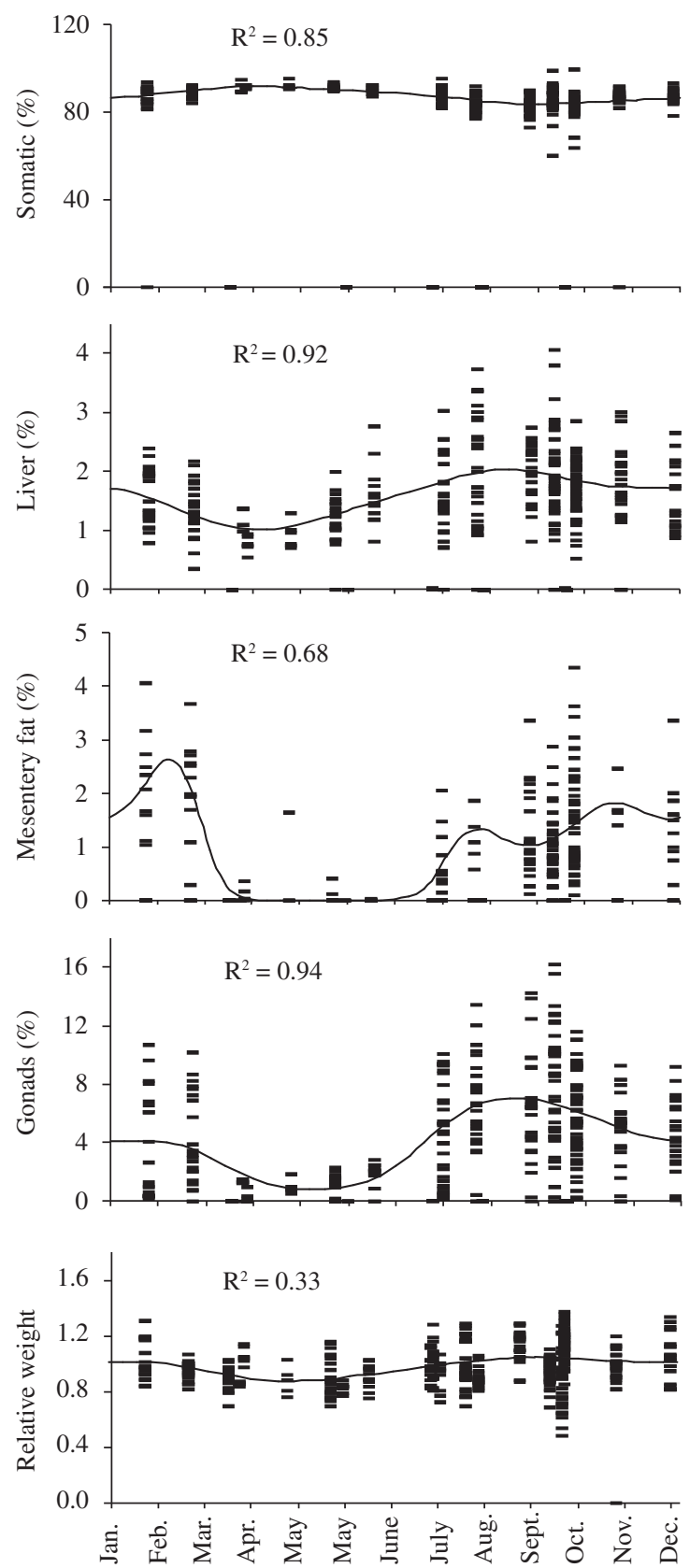

Males

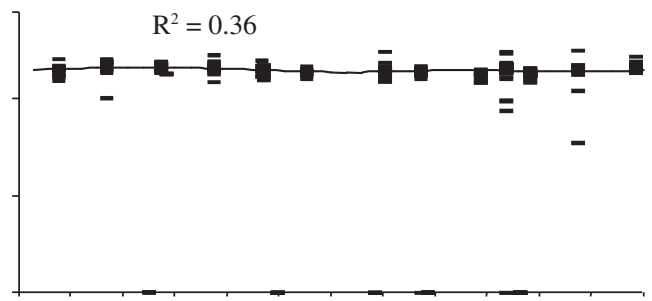

$\mathrm{R}^{2}=0.84$
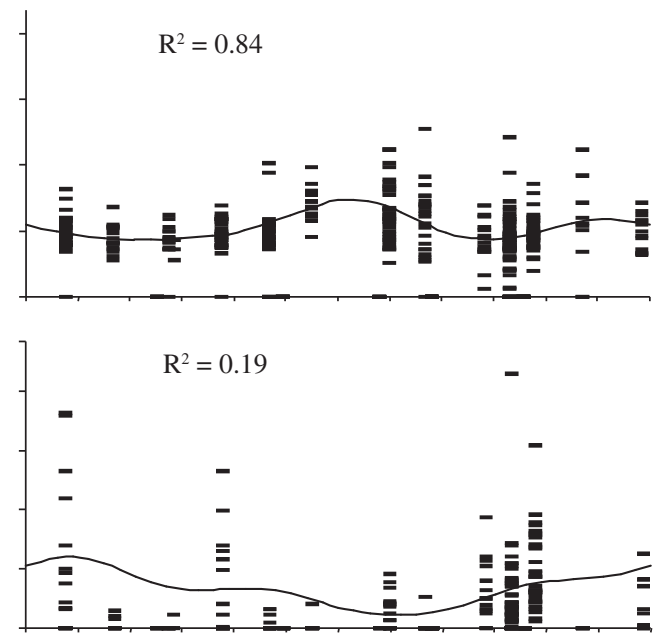

$\mathrm{R}^{2}=0.81$
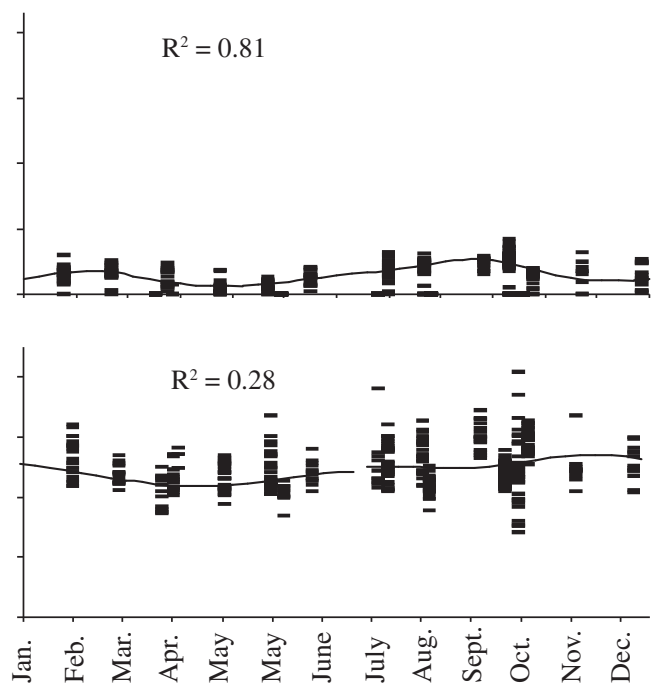

Figure 1. Weight index dispersion diagrams (-), fitted Fourier polynomial (continuous line) by gender throughout the year and coefficients of determination $\left(\mathrm{R}^{2}\right)$ for each fit.

mum in December. The Îmf diminishes gradually from December to July-August, presenting its lowest amount and growing until reaching a December maximum.

In relative terms, in females an increase of gonad, mesentery fat, and liver follows the zooplankton maximum. With a small delay with respect to that of zooplankton the Igo decrease is observed. Lowest zooplankton values correspond to highest mesenteric fat reserves
Table 2. Weight index variation coefficients by gender.

\begin{tabular}{lcc}
\hline & Females & Males \\
\hline Mesentery fat & 62.4973 & 73.2061 \\
Gonads & 63.0723 & 45.0776 \\
Liver & 25.7532 & 20.0707 \\
Relative Weight & 9.5717 & 8.6908 \\
Somatic & 3.6658 & 1.4179 \\
\hline
\end{tabular}




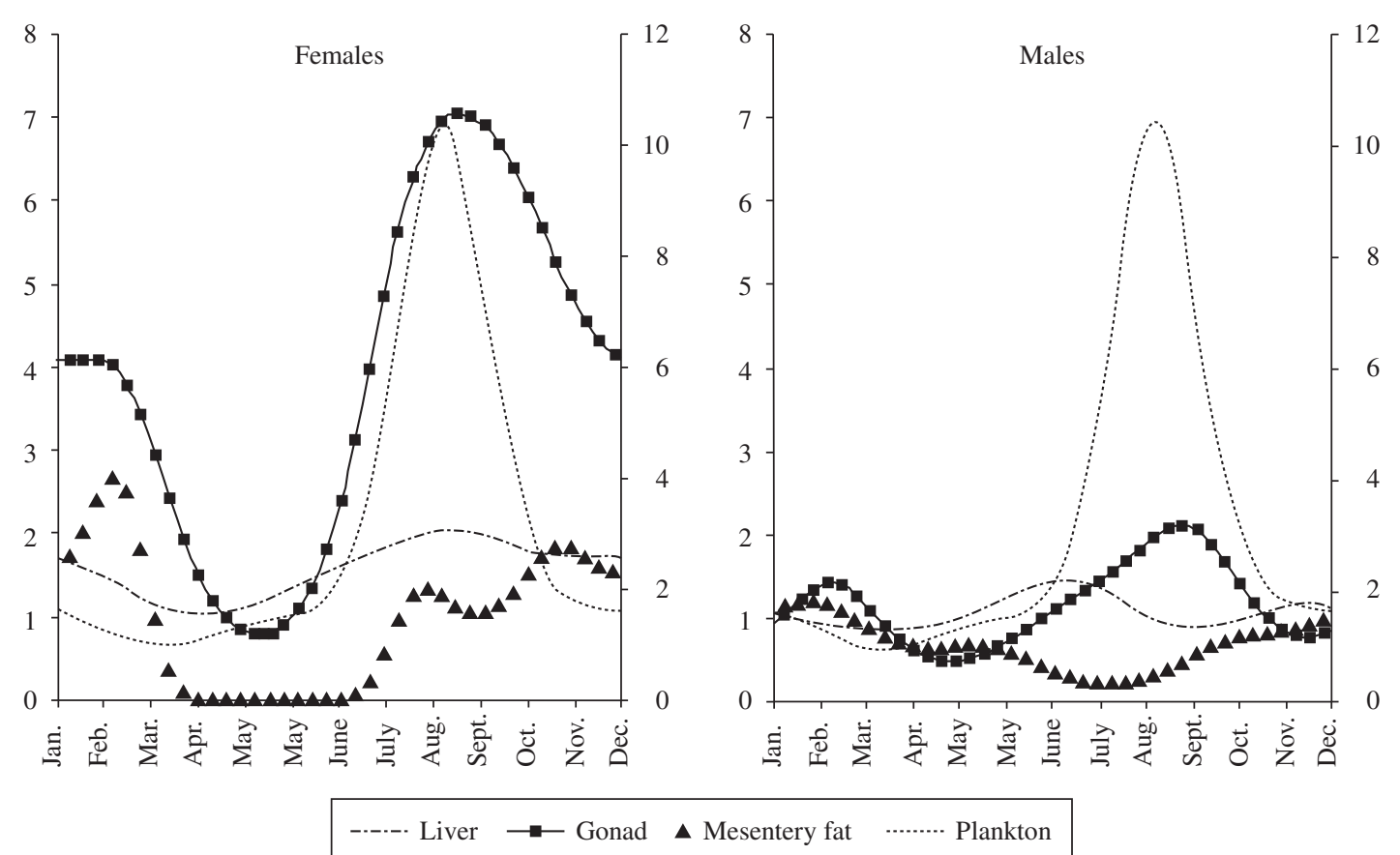

Figure 2. Annual cycle of weight index and energy contributed by zooplankton (cal/100 L).

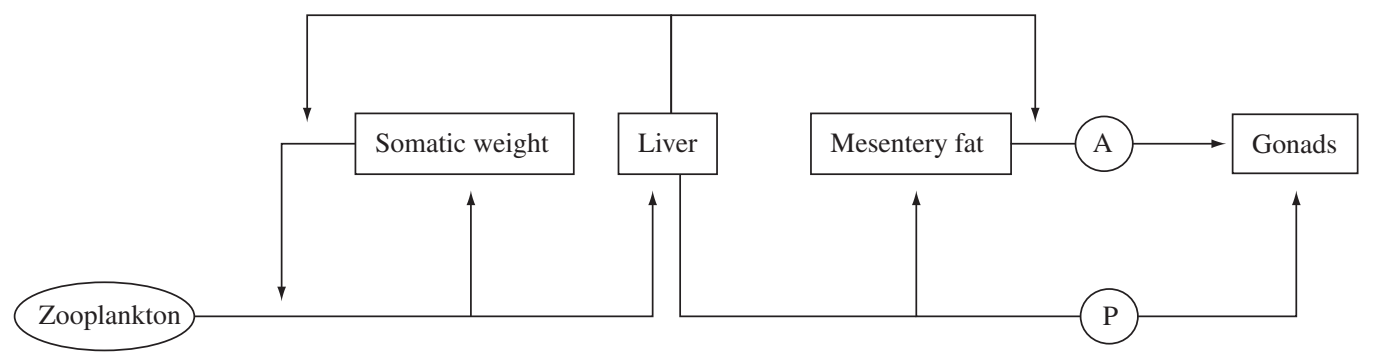

Figure 3. Conceptual diagram that represents energy transfer from food available to weight compartments of the Odontesthes bonariensis and its relation with reproduction. A) path: more active in autumn spawns; and P) path: in spring.

that are simultaneous to the growth of the Igo. The liver peak coincides with the ovaries great development, while its secondary maximum matches a quick decrease of gonads and accumulated fat.

Male gonads oscillate synchronously with female gonads, however the hepatic maxima are observed before the testicle growth and in proportional magnitude to the development of these. The Îmf is always lower in males than in females.

\section{Discussion}

For the considered size ranges, this fish species from the pampasic shallow lakes is predominantly zooplanktivorous, and available food was assessed as the energy zooplankton content with regard to silverside feeding efficiency (Ringuelet et al., 1980). The zooplankton community dynamics of Lacombe coincides with the descriptive general pattern for pampasic shallow lakes (Ringuelet, 1972) and world temperate lakes (Ravera, 1996). This pattern is reflected in the annual cycle of the zooplankton availability, which justifies relating it to the registered fluctuations in the analysed weight compartments. Therefore, this recurrent pattern is transmitted to the analysed compartments.

The values obtained for the coefficients of variation show that seasonal information contained in the data is noticeably more significant in mesentery fat, gonad and liver, being least important in somatic weight and relative weight. For this reason, they were not considered in the latter analyses (Figure 2).

In females, in February, fat reserves accumulated since August diminished simultaneously with gonad maturation, which culminated in February-March 
spawns, indicated by Îgo decline. The observed Îgo variations coincide with those informed by Cornejo (2003) for Lacombe and San Miguel del Monte shallow lakes. Liver performs a twofold function of reserve processor and glycogen and lipids labile reservoir, and it would exhibit its maximum activity in September-October to resolve ovarian development prior to the spring spawning period. The secondary liver maximum activity would be to administer the quick decrease of stored up mesentery fat propitiating autumn spawns. The Îms that is smaller in males and not as variable suggests that consumption dynamics and fat accumulation are different from those of females. This is related to the male reproductive behaviour, since they maintain a continuous activity during lengthy periods, according to Îgo.

Zooplankton values are lowest between summer and autumn and silversides rely on mesentery fat reserves for maintenance and eventual reproduction, assisted by liver (increase). Due to food shortage, liver only participates in maintenance during the rest of the autumn and early winter, administering mesentery fat reserve reduction. In spring, the liver would increase its activity to intervene in the new reserve accumulation when zooplankton increases.

In several fish species, visceral fat content does not present the same yearly behaviour in females and males (e.g., Henderson et al., 1996; Sutton et al., 2000). Mesentery fat varies more in silverside females than in the males (Figure 2) as observed by Henderson et al. (1996) in the "walleye", Stizostedion vitreum (Mitchill, 1818). The females of this species, who spawn in only one season, behave primarily as capital breeders because they derive necessary energy for reproduction. On the other hand, $O$. bonariensis females, who have two distinct spawning seasons (Boschi and Fuster de Plaza, 1959; Calvo and Morriconi, 1972; Strussmann, 1989; Cornejo, 2003), have a different behaviour type in autumn than in spring (Figure 3). While in autumn they behave more as capital breeders, in spring they would be more income breeder type, compensating the low fat reserves with derived energy entries from food toward the ovary through the liver. Silverside males present the same behaviour type. In autumn spawns they would use reserves obtained previously. In spring spawns, in which most of the mature population participates, they transfer energy directly from food through the liver to gonads.

It is evident that the zooplankton availability modulates fat reserves behaviour as well as physiologic activity (liver), and it would determine spawn intensity. Although the photoperiod and the temperature also participate in the control of these phenomena (Strussmann, 1989), in the present paper tangible evidences of these triggers cannot be offered.

Acknowledgements - Our special thanks to Engineer M. Martínez Leanes who facilitated field tasks and to Dr. L. Lunaschi and her collaborators who participated in the samplings and samples processing. We would also like to thank the Comisión de Investigaciones Científicas de la provincia de Buenos Aires and the Programa de Incentivos (Facultad de Ciencias Naturales y Museo, Universidad Nacional de La Plata), which partially financed this research

\section{References}

BAIGÚN, CR. and ANDERSON, RO., 1993. Structural indices for stock assessment of and management recommendations for pejerrey Odontesthes bonariensis in Argentina. North American Journal of Fisheries Management, vol. 13, no. 3, p. 600-608.

BERASAIN, G., VELASCO, CA. and CHICLANA, M., 1999. Historia de la piscicultura del pejerrey en Chascomús. In Anais dos Trabajos presentados en la $1^{o}$ Jornada de Historia de Chascomús, Mayo 14-15. Chascomús: Municipalidad de Chascomús. 20p. Mimeografiado.

BLACKWELL, BG., BROWN, ML. and WILLIS, DW., 2000. Relative weight (Wr) status and current use in fisheries assessment and management. Reviews in Fisheries Science, vol. 8, no. 1, p. 1-44.

BOSCHI, E. and FUSTER De PLAZA, E., 1959. Estudio biológico pesquero de pejerrey del embalse Río Tercero (Basilichthys bonariensis). Buenos Aires: Secretaria de Agricultura y Ganadería, Departamento de Investigaciones Pesqueras. Publicación No 8. 61p.

BROWN , ML. and MURPHY, BR., 2004. Seasonal dynamics of direct and indirect conditions indices in relation to energy allocation in largemouth bass Micropterus salmoides (Lacèpede). Ecology of Freshwater Fish, vol. 13, no. 1, p. 23-36.

CALVO, J. and MORRICONI, ER., 1972. Fenómenos reproductivos en el pejerrey (Basilichthys bonariensis). III) Estudio de la fecundidad, época y número de desoves. Anales de la Sociedad Científica Argentina, vol. III, no. CXIII, p. 75-84.

COLAUTTI, D. and REMES LENICOV, M., 2000. Primeros resultados sobre cría de pejerreyes (Odontesthes bonariensis) en jaulas: crecimiento, supervivencia, producción y alimentación. In GROSMAN, F. (Ed.). Fundamentos biológicos, económicos y sociales para una correcta gestión del recurso pejerrey. Azul: Editorial Astyanax. p. 53-61.

COLAUTTI, D., REMES LENICOV, M. and BERASAIN, G., 2003. Vulnerabilidad del pejerrey Odontesthes bonariensis a la pesca deportiva, en función de su condición. Biología Acuática, no. 20 , p. $49-55$.

COLAUTTI, D., REMES LENICOV, M. and BERASAIN, G., 2006. A satandard weight equation to assess the body condition of pejerrey Odontesthes bonariensis. Biocell, vol. 30, no. 1, p. $131-135$

CORNEJO, AM., 2003. Esterilidad en el pejerrey Odontesthes bonariensis en ambientes naturales. Biología Acuática, no. 20, p. 19-26.

ENCINA, L. and GRANADO-LORENCIO, C., 1997. Seasonal changes in condition, nutrition, gonad maturation and energy content in barbel, Barbus sclateri, inhabiting a fluctuating river. Environmental Biology of Fishes, vol. 50, no. 1, p. 75-84.

FREYRE,LR., 1976. Normas para la inspección y determinación del estado actual de ambientes pesqueros pampásicos. La Plata: Dirección de Recursos Naturales, Ministerio de Asuntos Agrarios de la Provincia de Buenos Aires. Mimeografiado.

FREYRE, LR., PROTOGINO, LC. and IWASZKIW, JM., 1983. Demografía del pejerrey Basilichthys bonariensis bonariensis 
(Pisces Atherinidae) en el Embalse Río Tercero, Córdoba: descripción de los artes de pesca. Biología Acuática, no. 4, p. 1-39.

FREYRE, LR., MAROÑAS, ME., SENDRA, ED. and CORNEJO, AM., 2005. Posibles causas de mortandad del pejerrey, Odontesthes bonariensis, en la laguna de Monte. Biología Acuática, no. 22, p. 119-122.

GÓMEZ, SE., 1998. Consideraciones sobre producción, cultivo y comercialización del pejerrey, Odontesthes bonariensis (Atherinidae) en la provincia de Buenos Aires (Argentina). Aprona Boletín Científico, vol. 11, no. 34, p. 2-8.

GROSMAN, F., 1995. El Pejerrey: ecología, cultivo, pesca y explotación. Buenos Aires: Ed. Astyanax. 132p.

GROSMAN, F., GONZÁlEZ, G., AGÜERIA, D. and SANZANNO, P., 2000. Ictiología del lago municipal de Colón (Argentina), como un ejemplo de dinámica ambiental. Revista AquaTIC, no. 10, p. 1-13.

HENDERSON, BA., WONG, JL. and NEPSZY, SJ., 1996. Reproduction of walleye in Lake Erie: allocation of energy. Canadian Journal of Fisheries and Aquatic Science, vol. 53, no. 1, p. 127-133.

LIAO, H., PIERCE, CL., WAHL, DH., RASMUSSEN, JB. and LEGGETT, WC., 1995. Relative weight as a field assessment tool: relationships with growth, prey biomass, and environmental conditions. Transactions of the American Fisheries Society, vol. 124 , no. 3 , p. 387-400.

MENNI, RC., 2004. Peces y ambientes en la Argentina continental. Monografías del Museo Argentino de Ciencias Naturales, no. 5. p. 1-316.
RAVERA, O., 1996. Zooplankton and trophic state relationships in temperate lakes. Memorie dell' Istituto Italiano di Idrobiologia, vol. 54, p. 195-212.

REY-PASTOR, J., Pi-CALlEJA, P. and TREJO, CA., 1987. Análisis Matemático Tomo 3: análisis funcional y aplicaciones. Buenos Aires: Editorial Kapelusz. p. 85-144. Capítulo XXV, Series e Integral de Fourier.

RINGUELET, RA., 1972. Ecología y bioecología del habitat lagunar o lago de tercer orden de la región neotropical templada (Pampasia sudoriental de la Argentina). Physis (Buenos Aires), vol. 31 , no. 82 , p. 55-76.

RINGUELET, RA., IRIAT, R. and ESCALANTE, AH., 1980. Alimentación del pejerrey (Basilichthys bonariensis, Atherinidae) en laguna Chascomús (Buenos Aires, Argentina): relaciones ecológicas de complementación y eficiencia trófica del plancton. Limnobios, vol. 1, no. 10, p. 447-460.

STRUSSMANN, CA., 1989. Basic studies in seed production of pejerrey Odontesthes bonariensis. Tokio: Department of Bioscience and Aquaculture Laboratory of Sea-Farming, University of Fisheries. 129p. Tese de Doutorado.

SOKAL, RR. and ROHLF, FJ., 1979. Biometría: principios y métodos estadísticos en la investigación biológica. Madrid: H. Blume Ediciones. 832 p.

SUTTON, SG., BULT, TP. and HAEDRICH, RL., 2000. Relationships among fat weight, water weight and condition factor in wild Atlantic salmon parr. Transactions of the American Fisheries Society, vol. 129, no. 2, p. 527-538.

ZAGARESE, HE., 1991. Planktivory by larval Odontesthes bonariensis (Atherinidae; Pisces) and its effects on zooplankton community structure. Journal of Plankton Research, vol. 13, no. 3 , p. $549-560$. 
